\title{
Governance Decisions in the Supply Chain and Quality Performance: The Synergistic Effect of Geographical Indications and Ownership Structure*
}

\author{
Susana López-Bayón ${ }^{\otimes 1}$, Manuel González-Díaz², \\ Vanesa Solís-Rodríguez ${ }^{3}$, Marta Fernández-Barcala ${ }^{4}$
}

1 Business Administration Department, University of Oviedo, Spain.

Facultad de Economía y Empresa, Avda. del Cristo s/n, 33071 Oviedo, Spain. E-mail: sbayon@uniovi.es.

Phone number: +34 985102813

2 Business Administration Department, University of Oviedo, Spain.

Facultad de Economía y Empresa, Avda. del Cristo s/n, 33071 Oviedo, Spain.

E-mail: mgdiaz@uniovi.es.

3 Business Administration Department, University of Oviedo, Spain.

Facultad de Economía y Empresa, Avda. del Cristo s/n, 33071 Oviedo, Spain.

E-mail: solisvanesa@uniovi.es.

4 Business Administration Department, University of Oviedo, Spain.

Facultad de Economía y Empresa, Avda. del Cristo s/n, 33071 Oviedo, Spain.

E-mail: mbarcala@uniovi.es.

* A first version of this paper has been presented in June 2016 at the 20th Annual Conference of the Society for Institutional \& Organizational Economics, Paris (http://papers.sioe.org/paris.html). We thank the participants for useful comments. Usual disclaimers apply.

$\bowtie$ Address correspondence to: Susana López-Bayón, Facultad de Economía y Empresa, University of Oviedo, Avda. del Cristo s/n, 33071 Oviedo, Asturias, Spain; Tel.: +34 985102 813; Fax: +34 985 103708. E-mail: sbayon@uniovi.es. 


\section{Highlights}

- Supply Chain governance decisions are related to quality performance by altering participant incentives.

- The average quality of wineries is positively associated with the adoption of the most stringent Gls.

- Cooperatives are related to the delivery of lower-quality products.

- The relative benefits of the most stringent geographical indications for improving final quality are intensified in cooperatives. 


\section{ACKNOWLEDGEMENTS}

The authors acknowledge the financial support provided by the Spanish Ministry of Economy and Competitiveness (Project ECO2013-40407-R). 


\title{
Governance Decisions in the Supply Chain and Quality Performance: The Synergistic Effect of Geographical Indications and Ownership Structure
}

\begin{abstract}
Although the supply chain (SC) management literature has extensively analyzed how features of SC relationships affect quality performance, it barely considers the role played by SC governance in managing and promoting quality performance. This study examines how quality performance is affected by two SC governance decisions in agri-food chains: (i) the adoption of a geographical indication (GI), and (ii) the creation of co-operative (co-op) ownership structures. Focusing on the wine industry, the study first examines how GIs encourage quality by improving vertical adaptation and leveraging resources (e.g., knowledge) of all SC members. Second, it analyzes how co-ops' collective action and horizon investment problems may hinder the delivery of high-quality products. The paper also examines how the effectiveness of GIs in promoting quality is contingent on the ownership structure of agri-food chains. Data from 327 wine producers and quality scores for 1,951 bottled wines are used to test the hypotheses. The results reveal that on average, the quality of wineries is positively associated with the adoption of the most stringent GIs. Second, although co-ops are negatively correlated with final quality compared to investor-owned firms (IOFs), this disadvantage is moderated when co-ops are certified under the most stringent GIs. However, these GIs are not related to wine quality within IOFs, suggesting that quality certifications are more effective when used within suitable governance structures.
\end{abstract}

Keywords Supply chain, Governance, Quality performance, Cooperatives, Geographical indications, Agri-food industry. 


\section{Introduction}

Quality management and its effect on performance has been an important issue in the Supply Chain Management (SCM) literature (e.g., Giunipero et al., 2008; Kaynak \& Hartley, 2008; Vanichchinchai \& Igel, 2011). This literature has extensively analyzed how the features of supply chain (SC) relationships (or links) affect performance, with product quality as one of the performance indicators (e.g., Rosenzweig et al., 2003; Swink et al., 2007; Wong et al., 2011; Schoenherr \& Swink, 2012; Huo et al., 2016; Ataseven \& Nair, 2017).

However, these studies have barely considered the role played by SC governance in managing and promoting quality performance. Recently, researchers have begun to address this gap by analyzing the influence of various governance problems (e.g., outsourcing, offshoring, and monitoring devices) on final quality (Gray et al., 2009, 2011; Handley \& Gray, 2013; Steven et al., 2014). However, we also observe a remarkable imbalance in the theoretical approach to how SC governance affects quality. Williamson (2008) argues that to assess the (adaptive) strengths and weaknesses of hybrid governance structures, which are the most relevant to SCM, the "salient attributes of governance [...] are incentive intensity [and] administrative command and control" (p. 8). This suggests that when analyzing SCM, incentive issues are as relevant as coordination problems. However, the dominant approach to studying adaptation issues in vertical relationships has been the coordination and cooperative approach proposed by Gulati et al. (2005). Indeed, the extant SCM literature about quality issues (e.g., Frohlich \& Westbrook, 2001; Rosenzweig et al., 2003; Koufteros et al., 2005, 2007; Narasimhan \& Nair, 2005; Robinson \& Malhotra, 2005; Sila et al., 2006; Swink et al., 2007; Mellat-Parast \& Digman, 2008; Kim, 2009; Flynn et al., 2010; Wong et al., 2011; Schoenherr \& Swink, 2012; Leuschner et al., 2013; Huo et al., 2016) has primarily addressed how customer requirements can be 
effectively satisfied by either combining resources or structuring SC participants' relationships (i.e., the coordination perspective). In contrast, the literature has barely considered how governance structures may affect SC participants' behavior by shaping their incentives.

The aim of this paper is to analyze how quality performance in the agri-food sector is affected by two SC governance decisions: the adoption of geographical indications (GIs) and the choice of the SC ownership structure, i.e., cooperatives (co-ops) versus investor-owned firms (IOFs). We argue that these governance decisions may influence quality by affecting SC agents' coordination and quality-provision incentives. We also analyze their interactive effect by examining whether GIs' effectiveness is affected by co-ops' incentive misalignment problems.

To address this question, we draw on the institutional and organizational economics literature, notably on transaction costs, property rights, and agency theories (Kim \& Mahoney, 2005; Dorobantu et al., 2017). This literature provides a relevant framework to describe and explain the choice of the organizational structure of supply chains (Hobbs, 1996; Williamson, 2008; Fernández-Barcala et al., 2017) based on the comparative effectiveness of governance mechanisms to solve not only coordination problems but also incentive problems. The empirical setting of the paper is the wine industry because of the special relevance that GIs and co-ops have in this sector.

First, GIs are the most widespread quality certification systems in the European agri-food sector (Ménard \& Valceschini, 2005; Rippon, 2014). They affect SC governance because they work as a third-party supply chain coordinator that integrates all firms across the agri-food chain for quality improvement by (i) establishing a list of quality standards or product specifications (i.e., raw material requirements, technical standards, or production methods) and (ii) performing verification and control functions to ensure SC partners' compliance with their standards. 
Second, there are two basic options for farmers and processors to govern their supply relationships: the co-op organization versus the classical IOF. Co-ops are of special interest here for two reasons. On the one hand, they are widespread in the wine industry. They account for more than $40 \%$ of the community wine production, making the wine industry the third most cooperative sector in the EU (Cooperativas Agro-alimentarias de España, 2016, p. 39). Particularly, in Spain, the country in which this paper is focused, $18.5 \%$ of wineries were co-ops in 2014 (Spanish Ministry of Agriculture and Fisheries, Food and Environment, MAPAMA, 2017a), and they reached a turnover of 1,219 million Euros in 2015 (Cooperativas Agroalimentarias de España, 2017, p. 98). On the other hand, co-ops are of special interest because of the incentives created by their unique governance structure in which suppliers (farmers) are forward integrated into processing firms. They are collectively owned by their suppliers, encouraging free-riding, collective action problems, and misalignment incentives that impair firm performance (Nilsson, 2001). An IOF owned by outside investors and rewarded with residual rent can avoid such difficulties (Hansmann, 1996).

Building on these arguments, the paper makes two basic contributions to the literature. On the theoretical side, we complement the works of Handley \& Gray (2013) and Steven et al. (2014), addressing other governance decisions that shape incentives to provide quality along the SC. First, we analyze how the adoption of more stringent GIs positively influences quality in the wine industry because they sustain and coordinate quality efforts throughout the SC. Second, we study how ownership structure directly affects wine quality because it shapes SC members' quality provision incentives. Particularly, it is argued that co-ops harm quality performance. Third, ownership structure has an indirect influence on quality performance because it moderates GIs' benefits. We argue that these benefits will be facilitated within the co-op organization, in 
which collective action problems would make more stringent GI coordination and monitoring devices more valuable. Conversely, more demanding GIs will exhibit less beneficial effects in IOFs.

On the empirical side, we are unaware of any other empirical study demonstrating that quality certification systems may be more effective when used within suitable governance structures in the SC. This corroborates Steven et al.'s (2014) call for more research on SC governance issues that examines moderating effects, which may help to explain contradictory findings in studies examining direct relationships. In this sense, this work sheds light on two contradictory empirical findings. First, there are conflicting results about whether the incentive problems caused by the co-ops result in a loss of quality (e.g., Cechin et al., 2013; Pennerstorfer \& Weiss, 2013). Second, the effectiveness of GIs in promoting quality and food value from the consumer perspective has been questioned because of its inconclusive results (for a recent review, see Grunert \& Aachmann, 2016). Our results show a positive relationship of GIs and a negative correlation of co-ops with wine quality. Moreover, they also show that both decisions must be analyzed jointly because more stringent GIs are not suitable for all types of firm but only for some (co-ops).

The rest of this paper is organized as follows. The next section presents the conceptual framework and research hypotheses. The following sections describe the research design and the empirical results. The final section offers implications and topics for future research. 


\section{Theoretical foundation}

\subsection{Effectiveness of GI certification systems}

GIs function as a collective quality certification system intended to guarantee the specific (and unobservable) characteristics of agri-food products attributable to their region of origin (e.g., soil, climate, local variety, local know-how, and working culture). GIs are usually valuable to consumers because they either make products more recognizable or guarantee specific organoleptic qualities. Well-known examples include Champagne, Parma ham, Roquefort cheese, and Rioja or Porto wines. GIs have become the main pillar of the European Union "quality policy" for agri-food sectors, and although they have been used for a long time (Maher, 2001), they currently constitute a growing phenomenon (Rippon, 2014). According to the DOOR and E_BACHUS databases, the number of registered GIs is almost 4,300 and has significantly increased in recent years (by September 2017, registered GIs included 2,891 wines and 1,403 agricultural products and foodstuffs).

Their credibility as a quality certification system is supported by an official certification body, which is responsible for performing both standardization and monitoring functions along the SC. First, certification bodies have to formalize a verifiable list of product specifications, namely, the quality standards required of all agents involved in the agri-food chain to bear the GI brand. These product specifications determine both the production processes of certified firms (e.g., agricultural practices) and the final characteristics of their agri-food products (e.g., organoleptic characteristics). Second, certification bodies must verify the compliance of all operators in the SC with GI norms. This monitoring function prevents the free-riding and opportunistic behavior that might otherwise be fostered by the collective nature of the GI 
(Winfree \& McCluskey, 2005). Namely, without such monitoring, firms entitled to use the collective label could circumvent the GI's quality standards while benefiting from its reputation.

It is worth noting that there are different types of GIs, depending on the strictness and complexity of their quality standards. Specifically, in the wine industry, European regulations define two basic types: protected designations of origin (PDOs), the most demanding, and protected geographical indications (PGIs), the least demanding (Regulation (EU) No 1308/2013). Compared with PGIs, typical PDOs are characterized by stronger connections to the region of origin and less freedom in production rules and in blending grape varieties (Deselnicu et al., 2013; Cacchiarelli et al., 2016a). Moreover, within each category, country-specific laws may differentiate further levels. For example, Spanish wines can be granted with a higher level of geographical certification, i.e., the qualified designation of origin $(Q D O)$, which is the most demanding within the PDO category because it involves the most rigorous standards affecting wine traceability, production, and distribution.

The potential of GIs to guarantee quality in agri-food markets has long been questioned. Previous studies have focused on the GIs' effectiveness in promoting value from the consumers' perspective, analyzing the consumer willingness to pay price premiums for a product's region of origin (for the wine industry see, for example, Boatto et al., 2011; Defrancesco et al., 2012; Galati et al., 2017). However, the reputation of GI labels, their associated price-premiums, and their actual level of utilization by potential producers differ significantly among GIs (Deselnicu et al., 2013; Grunert \& Aachmann, 2016). Critics argue that although they protect products with certain characteristics attributable to the product's place of origin, such protection may also restrict innovation and quality investments (Broude, 2005; Josling, 2006). For example, in the wine sector, non-GI products or less stringent GIs could take advantage of their flexibility in 
terms of variety, growing and processing conditions to better adjust to changes in consumer preferences or competitors' strategies (Cacchiarelli et al., 2016a). In addition, practitioners argue that the qualities attributable to the terroir are not necessarily `superior'; GI labels may assure consumers of a more genuine or traditional product but not the highest organoleptic qualities of top-quality wines (Ponte, 2009). For instance, various case studies have highlighted that GI producers perceive their certifications to be of low importance for product quality (e.g., Dimara et al., 2004; London Economics, 2008). In summary, GI products do not necessarily outperform those without geographical labels.

Furthermore, no empirical study has reported evidence for the ability of GIs to improve quality performance. Ultimately, this issue is important because their value as a strategic tool for differentiation depends largely on their ability to produce higher-quality products. The collective reputation of GIs should be associated with products of superior quality (Loureiro \& Umberger, 2007). Otherwise, they would simply burden consumers with an overload of terroir information of dubious value (Josling, 2006).

This paper argues that the potential value-enhancing role of GIs rests on their ability to facilitate vertical coordination and knowledge sharing throughout the entire agri-food chain. It is proposed that GIs will influence final quality by enabling effective SC quality management. This involves the "participation of all members of a supply-chain in the continuous and coordinated improvement of all processes, products and services" (Ross, 1998), instead of implementing quality programs only internally (at company level). This extension of quality practices to the entire chain is considered an important tool to improve final quality (e.g., Robinson \& Malhotra, 2005; Sila et al., 2006; Huo et al., 2016), especially for agri-food products. In this industry, quality issues pervade the entire SC; therefore, they cannot be reduced in only one stage of the 
chain. As a result, a coordinated response among farmers, processors, and distributors is essential for producing high-quality products (Ziggers \& Trienekens, 1999; Wever et al., 2010, 2012). Precisely, GIs operate as a wide-scope quality management system (Wever et al., 2010) that can produce vertical coordination and improve knowledge transfer among chain actors through a third-party supply chain coordinator (Masten \& Kim, 2015), i.e., the certification body.

First, GI specifications and controls facilitate vertical coordination by preventing all agents in the origin-labeled chain from distorting production practices, either opportunistically or accidentally, at the expense of quality (Lence et al., 2007). Second, chain-wide monitoring may play an important value-added role by facilitating valuable knowledge sharing at the SC level. The monitoring routines allow awareness of what is being learned (or missed) by different chain suppliers and processors. This information adds to GIs' stock of knowledge and thus can be used to help other chain actors keep abreast of new ideas to improve quality. Thus, Lewis et al. (2015) find that belonging to wine horizontal networks, i.e., formal networks of wineries stablished at regional level, facilitates access to new resources, valuable industry information, and technological know-how. Relatedly, certification bodies also boost inter-professional activities concerning the diffusion of quality-enhancing innovations (Cañada \& Vázquez, 2005). In conclusion, GIs function as a learning network that is able to create superior quality by effectively identifying and combining the diversity of knowledge that resides within the system (e.g., Powell et al., 1996; Dyer \& Nobeoka, 2000; Heide et al., 2014).

Finally, the ability to promote coordination and knowledge sharing throughout the supply chain depends on the type of GI scheme (PGI, PDO, or QDO). The most stringent GIs clearly require higher investments and production costs to meet their quality standards (e.g., Belletti et al., 2007; Mérel \& Sexton, 2012). However, in exchange, it is expected that stricter certification 
standards will drive greater variance reduction (in agricultural and industrial practices) and increased process control, which will strengthen the image of a unique product (Deselnicu et al., 2013; Cacchiarelli et al., 2016a) and prompt closer coordination and knowledge sharing within the agri-food chain. Taking into account the above arguments, and focusing on the wine industry, we propose the following hypothesis:

H1: The adoption of more stringent GIs (QDO) will enhance wine producers' quality in comparison with less stringent GIs.

\subsection{Impact of the SC ownership structure on quality: Co-ops versus IOFs}

To analyze quality issues, SCM must address the incentives (or disincentives) for all SC agents to promote quality practices and investments. Transaction cost theories argue that such incentives can vary significantly depending on the SC's governance structure (e.g., Williamson, 2008). In the agri-food sector, there are two central forms of governance that result from the adoption of two basic ownership structures: co-ops and IOFs.

Agricultural co-ops are firms collectively owned by an association of independent upstream farmers. In the case of the wine industry, co-ops are owned by an association of grape growers; the co-op first buys grapes from its proprietors (patrons) and then produces wine. Most agricultural co-ops have been established as a response to market failures and the necessity to enhance the economic and social well-being of their members (farmers) by providing them better terms of trade (Tennbakk, 2004; Boone \& Özcan, 2014). Specifically, by forming a co-op and owning the downstream partner, farmers can overcome information asymmetries and imbalances in their bargaining power vis-a-vis processor or distributor firms and thus deliver inputs at more favorable prices (Staatz, 1987; Bijman et al., 2012). 
Despite these rationales, drawing on property rights theories, prior studies have claimed that in most circumstances, co-ops represent weak competition against alternative forms of organization, especially IOFs (e.g., Cook, 1995; Fulton, 1995; Rey \& Tirole, 2007; Nilsson, 2001). This theoretical approach underlines how the allocation of property rights (asset ownership) may change ex ante investment incentives in non-contractible assets (Grossman \& Hart, 1986; Hart \& Moore, 1990; Ostrom, 2010). In this sense, it is suggested that the main feature impairing co-ops' performance is their lack of ownership specialization; more specifically, independent farmers delivering to an IOF are only suppliers of inputs, whereas they are also the proprietors in co-op firms. This ownership feature, along with their organizational principles ${ }^{1}$, result in (i) a dual nature of co-ops because they not only aim to be profitable but also provide a service to their farmer-owners (e.g., Soboh et al., 2012) and (ii) a set of vaguely defined property rights among co-ops' members (patrons) (Nilsson, 2001) ${ }^{2}$. Both features can induce several relative disadvantages of co-ops compared to IOFs. Particularly, two main problems regarding the provision of high-quality products have been recognized (Mérel et al., 2009; Saitone \& Sexton, 2009; Bijman et al., 2012; Pennerstorfer \& Weiss, 2013).

First, typical pooling practices of agricultural co-ops may result in collective action problems (e.g., free-riding) and adverse selection that affect input supply activities and thus the quality of the final product (Saitone \& Sexton, 2009; Liang \& Hendrikse, 2013). Co-ops are obliged to process all their members' supplies, even though farmers may supply either high- or low-quality produce. Moreover, co-ops' pooling practices imply an averaging process in which

\footnotetext{
${ }^{1}$ Particularly, the following organizational principles of co-ops can be considered fundamental: (1) voluntary and open membership, (2) democratic member control, and (3) members' economic participation.

${ }^{2}$ Specifically, the members' share in the society is not openly tradable, and its monetary value is generally redeemable at par value. In addition, profit distribution is not proportional to the members' equity share but instead to the quantity of products marketed through the co-op, i.e. they receive firm surplus in the form of better prices.
} 
producers share the expenses and returns associated with the commodity handled, independent of the quality delivered by each member (Hendrikse, 2011). These practices often fail to reward producers of the highest-quality products, i.e., producers have to bear the full costs associated with higher quality, while the benefits resulting from their effort are collectively shared with low-quality farmers, increasing the farmers' incentive to cheat on quality. Rational growers will anticipate this free-riding problem. Consequently, they will have strong incentives to deliver low-quality products to the co-op. Eventually, farmers of high-quality products will have no incentive to join the co-op; they will prefer to deliver their premium products to IOFs not bounded by pooling practices.

These incentive problems are particularly harmful in the case of the wine industry. Wine quality hinges on multiple interrelated factors, many of which are controlled by grape growers (soil characteristics and the agricultural practices used, among others). In reality, as the wine value-added increases, the required quality for wine grapes becomes more stringent and growers' requirements become more demanding (Goodhue et al., 2003). In this setting, collective action and adverse selection problems could place co-ops in a permanent position of disadvantage when competing in quality-differentiated markets.

To overcome these difficulties, various studies have suggested implementing strict quantity and quality rules through partial pooling practices (e.g., Bijman et al., 2012; Liang \& Hendrikse, 2013), which involves requiring co-op members to bring all of their production to the co-op and developing differential pricing policies based on quality evaluations of farm products. However, the quality requirements of premium grapes are not perfectly contractible. That is, the assessment of the grapes required for high-value wines is challenged by significant levels of uncertainty and high measurement costs (Hennessy, 1996; Goodhue et al., 2003; Fraser, 2005). 
In this sense, the use of differential pricing (i.e., partial pooling) may prove too costly to ensure high levels of quality within the co-op.

In contrast, IOFs can overcome these measurement costs by vertically integrating grapegrowing and placing hierarchical controls over their internal production methods (Hennessy, 1996). In fact, agency theory (Holmstrom \& Milgrom, 1991) has emphasized the difficulty of monitoring agents' outcomes as a primary factor explaining transaction costs in vertical relationships (Lafontaine \& Slade, 2007). Thus, regardless of the level of asset specificity, measurement difficulties, e.g., those surrounding high-quality supplies, will increase the probability of hierarchical coordination and vertical integration (e.g., Anderson \& Schmittlein, 1984; Wiggins \& Libecap, 1985).

Second, compared to IOFs, co-ops can also suffer from a horizon problem that can cause an underinvestment in long-term strategies (Vitaliano, 1983; Cook, 1995) and undermine quality improvements. Co-ops are financed primarily by their users' equity (and retained earnings), although equity shares are not transferable at a market price. Consequently, if farmers leave the co-op, they will have no access to the assets they contributed through their previous investments. Thus, patrons might be more interested in short-term returns than in long-term returns. This horizon problem is aggravated by the co-op principles of open membership and common ownership. Because "new" members of the co-op are treated like "old" members, the entrance of new farmers usually dilutes the equity of the current patrons, again undermining the motivation to invest in the co-op (primarily in the long term) because returns are not safeguarded against dilutions caused by new entrants. This reluctance to invest in riskier long-term strategies can lead to underinvestment in new technologies and branding strategies (characterized by long-term returns) that are necessary to support and communicate a high-quality differentiation policy. 

weakness of co-ops in producing high-quality products (wines). Thus,

H2: Compared to that of IOFs, the co-op ownership structure negatively influences wine producers' quality.

\subsection{Ownership structure as a moderator of the effectiveness of GIs}

Quality standards established by GIs determine product requirements that are useful to promote quality and terroir-based differentiation. However, as with other quality certification systems, the effectiveness of GIs may depend on the specific context in which they are deployed (Sousa \& Voss, 2008). As Zhang et al. (2012, p. 12) highlight, "taking a one-size fits all approach to quality management may not lead to optimal outcomes. Different organizations may need different approaches to quality". Building on this contingent approach, we argue that although GIs' specifications are expected to benefit all GI members, the effectiveness of the standards will vary depending on the ownership structure in which they are applied, i.e., co-ops vs. IOFs. More specifically, the inherent benefits of GIs' norms are expected to be greater in a co-op. The reason is twofold.

First, co-ops have a greater exposure to collective action problems than IOFs, which makes the ex post monitoring role of the certification body relatively more important. Moreover, the democratic principles of agricultural co-ops, i.e., all members (farmers) should actively participate in setting policies and have equal voting rights regardless of their shareholding, usually constrain their boards of directors from exerting direct authority and hierarchical control over farmers (patrons). As noted by Bijman et al. (2011), farmers will probably use the majority rules and their decision-making power to avoid losing autonomy at the farm level and to circumvent stricter internal rules, which would create a greater need for the external governance 
tool of the GI's certification body to compensate for poor-quality practices/incentives and deficient internal monitoring by co-ops. Qualifying for a GI also signals a credible commitment to its quality standards and fosters convergent goals toward a value-added strategy based on its code of practice, which is particularly beneficial for agricultural co-ops because they are characterized by the coexistence of two-sided objectives not always targeted toward firm profitability and quality differentiation, i.e., better prices for a group of heterogeneous farmers versus investor returns. In contrast, IOFs are essentially market-oriented entities and may use hierarchical controls over production processes more easily, for example, by vertically integrating into farm production. Likewise, because IOFs' managers are not controlled and constrained by suppliers, they can impose market discipline on growers more easily.

Second, co-ops may also take more advantage of the technological and commercial know-how developed by the GI's certification body than IOFs. Its monitoring function not only prevents opportunism but also offers valuable information feedback to farmers, enabling them to enhance their performance (Dyer \& Nobeoka, 2000; Heide et al., 2014; Lewis et al., 2015). Thus, the certification body plays an important role in signaling which product/process attributes must be met and/or corrected to enhance vertical coordination and to succeed in a qualitydifferentiated market. The access to this technological and commercial know-how is expected to be particularly helpful for co-ops because they are more exposed to the aforementioned horizon problem and, thus, to underinvestment in $\mathrm{R} \& \mathrm{D}$ and high-quality strategies (which are usually long term and riskier), which leads to a lack of valuable internal knowledge. Although the adoption of a GI might not directly alter the investment incentives of the co-op members, it can eventually counterbalance the drawbacks of such disincentives. 
In summary, the positive effect of GIs' quality standards on vertical coordination and quality improvement incentives is expected to be stronger within co-ops, which can be expressed in the following hypothesis:

H3: GIs' efficacy in promoting wine producers' quality will be stronger in co-op organizations (vs. IOFs).

\section{Research design}

\subsection{Data collection and sample}

We are interested in analyzing how governance decisions regarding the adoption of a GI and the choice of ownership structure interact with quality performance in agri-food chains. The empirical setting for this research is the wine industry in Spain, the country with the highest surface area of vineyards in the EU and the third-largest worldwide producer of wine (International Organization of Vine and Wine, 2017). Specifically, our population consists of Spanish wineries registered under a PDO.

The principal data source was a Spanish professional wine guide, Peñin Spanish Wine Guide (Peñín, 2006), which provides the most comprehensive list of the wineries that produce bottled wine in the various wine-producing regions of Spain. The guide offers general data about the wineries, such as hectares of vineyards held, storage capacity, and GIs endorsed by each winery, as well as annual information regarding professional quality scores for their wines. Other sources used to obtain information not provided by the guide (such as the ownership structure of each winery and their age) included the SABI database, which contains comprehensive information on companies in Spain, and the wineries' websites.

Specifically, the guide contains data from more than 2,000 wineries, representing more than $70 \%$ of all Spanish firms producing bottled wine under a GI (MAPAMA, 2004, 2006). 
However, it does not provide expert quality grades for all listed wines; thus, our final sample comprises 327 firms (with complete information on all variables included in the analysis), accounting for $27.7 \%$ of the total Spanish area of vineyards belonging to a PDO. Because each winery usually has more than one wine tested and graded, the sample included the scores for 1,951 wines. All of the sample wineries are registered under either a $Q D O$ or a PDO because the professional guide provides quality grades only for a very limited number of firms producing (a) wines without a GI (table wines) or (b) wines registered under a $\mathrm{PGI}^{3}$. Due to their lack of representativeness, these two types of wineries were not considered.

We compared this sample with the population for our key governance constructs, i.e., type of GI and ownership structure, and found no significant differences, thus suggesting an absence of sample bias. The composition and main characteristics of the dataset concerning these governance features are summarized below. Table 1 shows the distribution of the population and the sampled wineries according to their GIs of origin.

\footnotetext{
${ }^{3}$ Only $4 \%$ of the Spanish productive vineyard surface is devoted to produce non-GI wines. In addition, the wineries producing non-GI wines can also produce certified ones (i.e., they do not necessarily specialize in non-GI wine). Regarding the GI categories, PDO and QDO account for over 88\% of the total Spanish productive vineyard area (and 92\% of the area devoted to GI-labeled wines). (Data available in http://www.mapama.gob.es/es/estadistica/temas/estadisticas-agrarias/memofinalvinedo_tcm7-443391.pdf).
} 
Table 1

Population and sample distribution by GI

\begin{tabular}{lcc}
\hline Geographical Indication & $\begin{array}{c}\text { Sample } \\
\text { distribution }\end{array}$ & $\begin{array}{c}\text { Population } \\
\text { distribution }\end{array}$ \\
\hline (c)
\end{tabular}

The QDO La Rioja is the most important GI in terms of the number of wineries and the volume of wine produced. Along with La Rioja, Priorat is the other QDO in Spain and represents $2 \%$ of the wineries in both the dataset and the population. Thus, the sample resembles the entire population in terms of the wineries registered under a QDO (approximately 22\% of wine producers).

Although there are many PDOs for Spanish wines, they differ significantly in terms of both the volume of wine processed and the number of wineries registered under each PDO. According to MAPAMA (2006), most wineries producing bottled wine are registered under five PDOs (Ribera del Duero, Cava, La Mancha, Rías Baixas, and Penedés), which are the most relevant in terms of the number of affiliates. The remaining producers are widely dispersed among numerous minor PDOs in both the population and the sample. These features have been maintained over time and are properly reproduced in our dataset (see Table 1).

Regarding the ownership structure of the supply chain (co-ops vs. IOFs), co-ops have a strong presence in this sector; they produce more than $60 \%$ of all wine (Bijman et al., 2012, p. 
47). However, co-ops sell most of their wine in bulk to other wineries; thus, they account for a small percentage of the bottled wine market. Compared to IOFs, the number of co-ops that produce and commercialize bottled wine is quite small (Giagnocavo \& Vargas-Vasserot, 2012), as reflected in the lower proportion of co-ops comprising our dataset-33\% of the sampled wineries are co-ops (108 cases), whereas 67\% are IOFs (219 cases).

\subsection{Variables and measures}

Dependent variable. The theoretical model focuses on how SC ownership structures and GI certification systems are related to the quality performance of firms (i.e., wineries). Following previous studies (e.g., Benjamin \& Podolny, 1999; Scott-Morton \& Podolny, 2002; Frick, 2004; Pennerstorfer \& Weiss, 2013; Cacchiarelli et al., 2016a), our measure of quality was obtained from a professional wine guide (Peñin Spanish Wine Guide). Quality ratings provided by professional guides are produced by wine experts following highly systematized procedures and rigorous standards of evaluation. As a result, these ratings show a high convergent validity across independent evaluations, i.e., wines considered high/average/poor quality by one set of independent evaluators are generally considered high/average/poor quality by other evaluators, due to the aesthetic properties of the wine itself instead of external factors such as the wine's price or origin. Ultimately, these properties help to ensure the reliability of expert ratings as quality measures of wine (Benjamin \& Podolny, 1999).

Thus, we first defined wine quality as the rating reported in the guide for a given wine. This guide uses Robert Parker's rating system (e.g., Ali et al., 2008), which grades any wine using a 50 to 100 scale, ranging wines from unacceptable (those nearer to 50) to "extraordinary" (those closer to 100). Following Crozet et al. (2012) and Barthélemy (2017), we assessed the 
reliability of the guide's quality measures by comparing these measures with those obtained from one of the most influential international wine guides, The Wine Advocate, developed by R.M. Parker. We identified all wines with quality scores in both guides for the same time period. A test of means did not reveal any significant difference in the average scores between the two groups of evaluations. Moreover, the Pearson correlation was found to be 0.47 , indicating that the two sets of rankings are reasonably correlated and seem to agree in their scores. Because the Peñin Spanish Wine Guide is much more comprehensive than the alternative sources of quality ratings for Spanish wines, we relied upon it for our subsequent analysis.

The overall quality of each winery (QUALITY) was then operationalized as the average quality ratings of all wines reported for each winery. As mentioned above, the final dataset includes quality information for 1,951 wines produced by 327 wineries. It is noteworthy that the mean value of QUALITY (82.8) is relatively high, which might suggest skewness toward higherquality wines in the dataset. In this regard, previous studies have alleged that wines of inferior quality are often deliberately under-represented in wine guides for commercial reasons (Benjamin \& Podolny, 1999; Bramley et al., 2009; Pennerstorfer \& Weiss, 2013). We cannot completely reject a potential bias in our dataset toward wines pursuing a minimum level of quality. However, the wide coverage of our professional wine guide (which includes more than $70 \%$ of Spanish firms producing bottled wine under a GI and evaluates more than $85 \%$ of their listed wines) may attenuate such bias.

Independent variables. Consistent with the proposed hypotheses, the independent variables were set to be (1) the ownership structure of wine producers and (2) the type (i.e., stringency) of the GI adopted. 
Ownership structure. COOP is a dummy variable coded as " 1 " if the winery was a co-op, and "0" otherwise (i.e., an IOF). We also used IOF, which is a dummy variable using the reverse coding (i.e. takes " 1 " if the winery is an IOF and " 0 " otherwise).

Type of GI. To capture the strictness and complexity of GIs' certification standards, we included a dummy variable $(Q D O)$ coded as " 1 " if the winery was registered under a $Q D O$ and " 0 " if the winery was registered as a PDO.

Control variables. Other factors besides ownership structure and GI regulations may affect the quality performance of the wineries. First, previous literature emphasizes the relationship between knowledge created by firm experience (learning economies) and performance (for a review, see, for example, Argote, 1999). Particularly, older wineries may produce higher-quality wines only because they reach a better understanding of the production process as experimental learning accumulates. Accordingly, we used the winery's age (number of years since its foundation) as a proxy for this learning effect (EXPERIENCE). We expected a non-linear effect of this variable, reflecting the need for time to develop the resources and know-how required for production. Thus, a squared term (EXPERIENCE ${ }^{2}$ ) was introduced into the model together with its direct effect.

Second, various studies conducted in the wine industry have suggested a negative relationship between the wineries' size in terms of their scale of production and their orientation toward high quality (e.g., Oczkowski, 1994; Scott-Morton \& Podolny, 2002). From this perspective, small wineries tend to specialize more in high-end wines to differentiate themselves from more efficient and larger producers (Oczkowski, 1994). Consistent with previous research 
(e.g., Benjamin \& Podolny, 1999; Scott-Morton \& Podolny, 2002), to reflect the firms' size, we used the STORAGE capacity of the winery (in liters).

Finally, to account for potential endogeneity problems, we used two variables, HECTARES and MULTI-GIs (see discussion in next section). HECTARES measures the vineyard hectarage owned by the wineries. MULTI-GIs is a dummy variable coded as 1 for wineries producing wines from various GIs and 0 for those registered exclusively under a single GI.

Table 2 provides the definition of the variables used in the model, and Table 3 lists their descriptive statistics and correlations.

Table 2

Variable definitions

\begin{tabular}{|c|c|}
\hline Dependent variable & Definition \\
\hline QUALITY & $\begin{array}{l}\text { Average quality ratings of all wines reported for each } \\
\text { winery }\end{array}$ \\
\hline \multicolumn{2}{|c|}{ Independent and control variables } \\
\hline COOP & 1 if the winery is a co-op; 0 if it is an IOF \\
\hline IOF & 1 if the winery is an IOF; 0 if it is a coop \\
\hline QDO & $\begin{array}{l}1 \text { if the winery is registered under a } Q D O ; 0 \text { if it is } \\
\text { registered as a PDO }\end{array}$ \\
\hline EXPERIENCE & Number of years since the winery's foundation \\
\hline STORAGE & Storage capacity of the winery \\
\hline HECTARES & Vineyard hectarage owned by the winery \\
\hline MULTI-GIs & $\begin{array}{l}1 \text { if the winery produces wines from various Gls; } 0 \text { if it } \\
\text { is registered exclusively under a single Gl }\end{array}$ \\
\hline
\end{tabular}


Table 3

Means, standard deviations, and correlations among variables

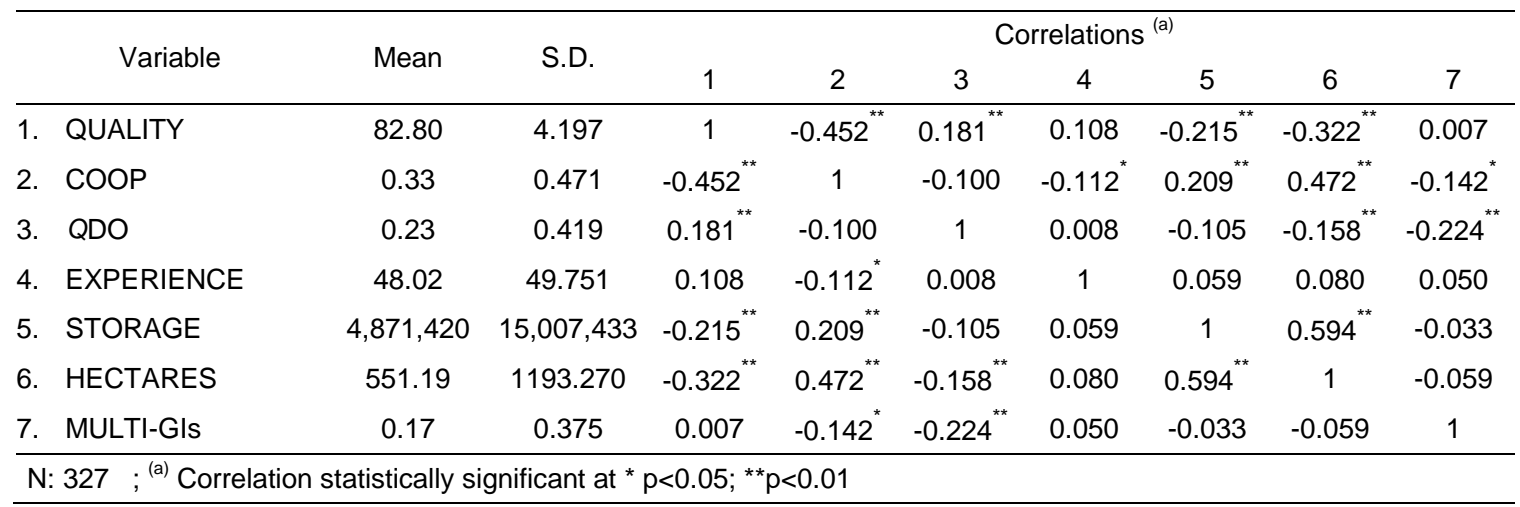

\section{Analysis and results}

\subsection{Description of the model}

We tested our hypotheses with a regression involving the moderating effect of the ownership structure (co-op vs. IOF) on the relationship between the type of GI certification ( $Q D O$ vs. PDO) and quality performance (see Equation [2] below). An important concern in this model is sample selection bias. The idea that organizational decisions are endogenous to their expected performance outcomes (Masten, 1996; Shaver, 1998; Hamilton \& Nickerson, 2003) is a recurrent issue in studies analyzing governance mode choice.

In our model, wine producers might anticipate co-op conflicts and self-select into governance structures (co-ops vs. IOFs) based on their quality orientations. Specifically, co-ops could anticipate relevant agency problems from their ownership structure and strategically choose to produce and commercialize low-quality products. Because such choices are made systematically and not randomly, standard OLS estimates could lead to biased coefficients. To address the potential for sample selection bias, we used a two-step correction procedure based on Heckman (1979). The first step involved estimating a treatment model to describe the selfselection decision (Equation [1]). The equation of interest (Equation [2]) was then estimated after 
being adjusted for self-selection from the first equation. Maddala (1983, p. 122) shows the log likelihood function to be maximized.

The treatment equation in this study is a probit model that predicts the probability of choosing a co-op or an IOF as follows:

$$
\begin{aligned}
& \text { COOP }_{i}^{*}=\alpha_{0}+\alpha_{1} \text { ODO }_{i}+\alpha_{2} \text { EXPERIENCE }_{i}+\alpha_{3} \text { EXPERIENCE }_{i}^{2}+ \\
& +\alpha_{4} \text { STORAGE }_{i}+\alpha_{5} \text { HECTARES }_{i}+\alpha_{6} \text { MULTIGIs }_{i}+v_{i}
\end{aligned}
$$

where $v_{i}$ is a random error term, and $\operatorname{COOP}_{i}^{*}$ represents an underlying index of the ownership structure. If $\operatorname{COOP}_{i}^{*} \leq 0$, then $\operatorname{COOP}_{i}=0$ and corresponds to IOF wineries; if $\operatorname{COOP}_{i}^{*}>0$ then $C O O P_{i}=1$ and correspond to co-op wineries.

The specification of the main equation (for quality performance determinants) is as follows:

$$
\begin{aligned}
& \text { QUALITY }_{i}=\beta_{0}+\beta_{1} \text { QDO }_{i}+\beta_{2} \text { COOP }_{i}+\beta_{3} \text { QDO }_{i} * \text { COOP }_{i}+ \\
& +\beta_{4} \text { EXPERIENCE }_{i}+\beta_{5} \text { EXPERIENCE }_{i}^{2}+\beta_{6} \text { STORAGE }_{i}+\mu_{i}
\end{aligned}
$$

where $\mu_{i}$ is a random error term and QUALITY is the overall quality of each winery. Econometrically identifying Equation [1] requires introducing at least one instrument not considered in the performance regression into the treatment regression. As discussed above, we used (1) HECTARES and (2) MULTI-GIs as instruments for the endogenous variable (COOP). A leading motivation for farmers to join a co-op is to achieve sufficient size to counterbalance the market power of the processor and marketing firms and provide growers with better prices (Staatz, 1987; Tennbakk, 2004). Wine co-ops are owned by numerous independent farmers (vineyard proprietors) who supply wine grapes to the winery. Simultaneously, the co-op is obliged to process all its members' supplies, which diminishes its dependency on external sourcing. In contrast, investor-owned wineries are not committed to vertically integrating backward into agricultural production; thus, they could easily outsource most of their supplies to 
external vine growers if necessary. Additionally, vineyard holdings have traditionally been highly fragmented into small-scale farming in Spain; thus, there are relatively few large landholders owning great extensions of land (77\% of Spanish vineyard holdings are under 1 ha, MAPAMA, 2017b, p. 12). This fragmentation has made the transmission and concentration of large extensions of land ownership into the hands of a single firm more difficult (e.g., Allen \& Lueck, 1998). Nevertheless, co-ops do not experience such difficulties. The co-op organization constitutes an easy way to concentrate and control large extensions of vineyards under a single winery because it does not require formal land transfers from numerous (and small) vineyard holdings. By definition, under a co-op, the land proprietors (grape growers) collectively own the winery, which pools their resources and controls their production. In summary, co-ops can concentrate large extensions of vineyards more easily than IOFs; thus, HECTARES was entered as a predictor in the first stage.

Regarding the second instrument, MULTI-GIs, it is expected that conflicts among co-op members over different pricing policies make it more difficult for co-ops to qualify for various GIs. If a co-op establishes different prices for the grapes (e.g., depending on their GI), less favored members will likely complain about favorable treatment toward higher-paid farmers. Less favored growers will try to pool revenues and establish a uniform pricing rule (i.e., dependent on the amount of grapes delivered instead of the real market value of grapes), likely because both the farmers are the proprietors and co-ops' democratic principles can allocate the majority of voting rights to lower-paid and/or less-value-adding farmers. In this case, the producers of the most highly valued GIs will eventually leave the co-op. In contrast, an IOF's product diversification strategy is less dependent on its current sources of supply and their specific (and heterogeneous) interests (i.e., grape-growers cannot interfere with winery 
strategies). As a result, producing wines from different geographical areas of origin is expected to be less costly and less problematic for IOFs than for co-ops.

\subsection{Results}

Table 4 shows the results of the quality performance equation estimates. Model 1 examines the direct relationship between the governance characteristics of the supply chain (type of GI and ownership structure) and quality (basic model), whereas Model 2 analyzes the moderating effect of ownership structure on the effectiveness of GIs. In the latter, because the interaction term involves a dummy variable (COOP), the effect of the variable measuring the type of GI on quality is interpreted as its effect on the control group (i.e., IOFs). Consequently, to test the main effects of the GI's type on quality within the co-op group, we re-estimated this regression using the reverse coding of the co-op dummy variable (i.e., IOF). This is the reason why we also distinguish between the (a) left-panel models estimated using the COOP dummy and the (b) right-panel models, which are re-estimations of these regressions using the IOF dummy variable. Overall, all models have significant Wald Chi-squared statistics.

Although this is not our focus, the first column shows the results for the treatment regression (COOP and IOF models). Both HECTARES and MULTI-GIs are significant and have the expected sign on ownership structure, indicating that it is possible to use the treatment effect model $^{4}$. The likelihood ratio test indicates that Rho estimates are significantly different from zero in all models, suggesting that the equations are not independent because bias selection

\footnotetext{
${ }^{4}$ These variables have no effect on quality performance, thus reinforcing the argument that they predict ownership structure but not quality performance. The results are available upon request.
} 
is statistically significant. Therefore, Heckman's correction is appropriate ${ }^{5}$. Finally, the variance inflation factor (VIF) test did not show any collinearity problems between variables, namely, it did not exceed the cut-off point of 10 (Hair et al., 1995) (max. value of 3.64).

Turning to the hypothesis tests, first, it must be noted that the coefficient for $Q \mathrm{DO}$ is positive and significant $(\beta=1.2017, \mathrm{p}<0.05)$, as seen in Model 1 (Table 4). This result supports the first hypothesis that firms producing under more stringent GIs are positively associated with higher-quality performance. Thus, producers with a $Q D O$ obtain better overall scores for their wines than wineries applying for less stringent certifications (PDOs), suggesting that stricter GIs may ensure better coordination and knowledge sharing among the SC actors, leading to higher levels of quality.

The parameter for the COOP variable is also significant and, as expected, negative (Table 4, left panel, Model 1a: $\beta=-4.7855, \mathrm{p}<0.01)$. The parameter has the opposite sign when we run the model with the IOF dummy variable (Model 1b). This result supports hypothesis 2, suggesting that the co-op organization is negatively associated with wine quality. Specifically, it points to the hypothesized difficulties of agri-food co-ops compared to IOFs in providing correct incentives for quality (e.g., potential free-riding problems among members and underinvestment or horizon problems).

The results also support hypothesis 3, which establishes that the effectiveness of GIs depends on their fit with the ownership structure of the supply chain. The positive and significant coefficient of the interaction term $Q D O \times \operatorname{COOP}$ (Table 4, left panel, Model 2a: $\beta=1.9709$, $\mathrm{p}<0.1$ ) indicates that more stringent GIs are particularly useful in a co-op organization.

${ }^{5}$ This ratio test is a comparison of the joint likelihood of an independent probit model for the selection equation and a regression model for the observed data against the likelihood of the treatment effect model (Guo \& Fraser, 2009, p. 103). 
Moreover, because the interaction term involves a dummy variable for the governance structure, the relationship between quality performance and adopting more stringent certifications $(Q D O)$ can be observed separately for the two governance forms (co-ops and IOFs). Thus, the relationship between $Q D O$ and quality cannot be interpreted for the full sample of firms when the interaction term is included in Model 2. Instead, it must be interpreted as the effect of this variable on the control group: the group of IOFs on Model 2a and the group of the co-ops on Model $2 \mathrm{~b}$. Whereas $Q D O$ has a positive association with quality within the co-op group (Table 4, Model 2b: $\beta=2.6661, p<0.01), Q D O$ has no significant association with quality among the group of IOFs (Table 4, Model 2a: $\beta=0.6952, p>0.05$ ).

The STORAGE capacity variable has a negative and significant relationship with quality in all models, which means that as a winery's size increases, the average quality of its bottled wines decreases. This result is consistent with the idea that small producers tend to specialize more in high-end wines to differentiate themselves from larger producers (Oczkowski, 1994).

Finally, the EXPERIENCE variable exhibits a positive and significant non-linear relationship with quality in all models. This result reflects the presence of a learning effect in the wine industry. 
Table 4 Regression models

\begin{tabular}{|c|c|c|c|c|c|c|c|}
\hline \multicolumn{4}{|c|}{ (a) Model using dummy variable Co-op } & \multicolumn{4}{|c|}{ (b) Model using dummy variable IOF } \\
\hline $\begin{array}{l}\text { Dependent } \\
\text { variable }\end{array}$ & COOP & $\begin{array}{c}\text { Model 1a } \\
\text { QUALITY } \\
\text { (basic model) }\end{array}$ & $\begin{array}{c}\text { Model 2a } \\
\text { QUALITY } \\
\text { (interactive effects) }\end{array}$ & $\begin{array}{l}\text { Dependent } \\
\text { variable }\end{array}$ & IOF & $\begin{array}{c}\text { Model 1b } \\
\text { QUALITY } \\
\text { (basic model) }\end{array}$ & $\begin{array}{c}\text { Model 2b } \\
\text { QUALITY } \\
\text { (interactive effects) }\end{array}$ \\
\hline (Constant) & $\begin{array}{c}-1.2355^{* * *} \\
(-6.03)\end{array}$ & $\begin{array}{c}84.3928 * * * \\
(197.49)\end{array}$ & $\begin{array}{c}84.4234 * * * \\
(198.92)\end{array}$ & (Constant) & $\begin{array}{c}1.2355^{* * *} \\
(6.03)\end{array}$ & $\begin{array}{c}79.6072 * * * \\
(137.46)\end{array}$ & $\begin{array}{c}79.3828 * * * \\
(134.85)\end{array}$ \\
\hline QDO & $\begin{array}{c}-0.1113 \\
(-0.53)\end{array}$ & $\begin{array}{c}1.2017^{* *} \\
(2.44)\end{array}$ & $\begin{array}{c}0.6952 \\
(1.24)\end{array}$ & QDO & $\begin{array}{c}0.1113 \\
(0.53)\end{array}$ & $\begin{array}{c}1.2017^{* *} \\
(2.44)\end{array}$ & $\begin{array}{c}2.6661 * * * \\
(2.81)\end{array}$ \\
\hline COOP & & $\begin{array}{c}-4.7855^{* * *} \\
(-6.98)\end{array}$ & $\begin{array}{c}-5.0406 * * * \\
(-7.23)\end{array}$ & IOF & & $\begin{array}{c}4.7855^{* * *} \\
\quad(6.98)\end{array}$ & $\begin{array}{c}5.0406^{* * *} \\
(7.23)\end{array}$ \\
\hline QDO x COOP & & & $\begin{array}{c}1.9709^{*} \\
(1.80)\end{array}$ & QDO $\times$ IOF & & & $\begin{array}{c}-1.9709 * \\
(-1.80)\end{array}$ \\
\hline EXPERIENCE & $\begin{array}{c}0.0384 * * * \\
(3.80)\end{array}$ & $\begin{array}{c}-0.0086 \\
(-1.11)\end{array}$ & $\begin{array}{c}-0.0070 \\
(-0.91)\end{array}$ & EXPERIENCE & $\begin{array}{c}-0.0384 * * * \\
(-3.80)\end{array}$ & $\begin{array}{c}-0.0086 \\
(-1.11)\end{array}$ & $\begin{array}{c}-0.0070 \\
(-0.91)\end{array}$ \\
\hline EXPERIENCE $^{2}$ & $\begin{array}{c}-0.0004^{* * *} \\
(-3.86)\end{array}$ & $\begin{array}{c}5.54 \mathrm{e}-05^{*} \\
(1.96)\end{array}$ & $\begin{array}{c}5.14 \mathrm{e}-05^{*} \\
(1.82)\end{array}$ & EXPERIENCE $^{2}$ & $\begin{array}{c}0.0004 * * * \\
(3.86)\end{array}$ & $\begin{array}{c}5.54 \mathrm{e}-05^{*} \\
(1.96)\end{array}$ & $\begin{array}{c}5.14 \mathrm{e}-05^{*} \\
(1.82)\end{array}$ \\
\hline STORAGE & $\begin{array}{c}-2.36 \mathrm{e}-08 * * * \\
(-3.53)\end{array}$ & $\begin{array}{c}-2.77 e-08^{*} \\
(-1.92)\end{array}$ & $\begin{array}{c}-2.65 e-08^{*} \\
(-1.85)\end{array}$ & STORAGE & $\begin{array}{c}2.36 \mathrm{e}-08 * * * \\
(3.53)\end{array}$ & $\begin{array}{c}-2.77 e-08^{*} \\
(-1.92)\end{array}$ & $\begin{array}{c}-2.65 e-08^{*} \\
(-1.85)\end{array}$ \\
\hline HECTARES & $\begin{array}{c}0.0012^{* * *} \\
(5.98)\end{array}$ & & & HECTARES & $\begin{array}{c}-0.0012^{* * *} \\
(-5.98)\end{array}$ & & \\
\hline MULTI-GIs & $\begin{array}{c}-0.7723^{* * *} \\
(-2.83)\end{array}$ & & & MULTI-GIs & $\begin{array}{c}0.7723^{* * *} \\
(2.83)\end{array}$ & & \\
\hline $\mathbf{N}$ & 327 & 327 & 327 & $\mathbf{N}$ & 327 & 327 & 327 \\
\hline Wald test & & $93.99 * * *$ & $98.55^{* * *}$ & Wald test & & $93.99 * * *$ & $98.55^{* * *}$ \\
\hline Rho & & $\begin{array}{c}0.3084^{* *} \\
(2.35)\end{array}$ & $\begin{array}{c}0.2758^{* *} \\
(2.09)\end{array}$ & Rho & & $\begin{array}{c}-0.3084 * * \\
(-2.35)\end{array}$ & $\begin{array}{c}-0.2758^{* *} \\
(-2.09)\end{array}$ \\
\hline $\begin{array}{l}\text { LR test of indep. } \\
\text { eqns. }(r h o=0)\end{array}$ & & $5.55^{* *}$ & $4.40 * *$ & $\begin{array}{l}\text { LR test of indep. } \\
\text { eqns. (rho }=0)\end{array}$ & & $5.55^{* *}$ & $4.40 * *$ \\
\hline
\end{tabular}

$t$ statistics are in parentheses; ${ }^{*} p<0.1 ;{ }^{* *} p<0.05 ;{ }^{* * *} p<0.01$ 


\section{Interaction graphs}

To reinforce the above results, we plotted the interaction effect, as shown in Figure 1.

The figure shows two coordinate axes, (a) and (b), for the relationship between the type of GI (the $x$-axis) and quality performance (y-axis), one for each value of the moderating variable (ownership structure).

\section{Figure 1}

Interaction effect of the ownership structure (co-op vs. IOF) and the type of GI ( $Q$ DO vs. PDO) on quality performance

(a) IOFs

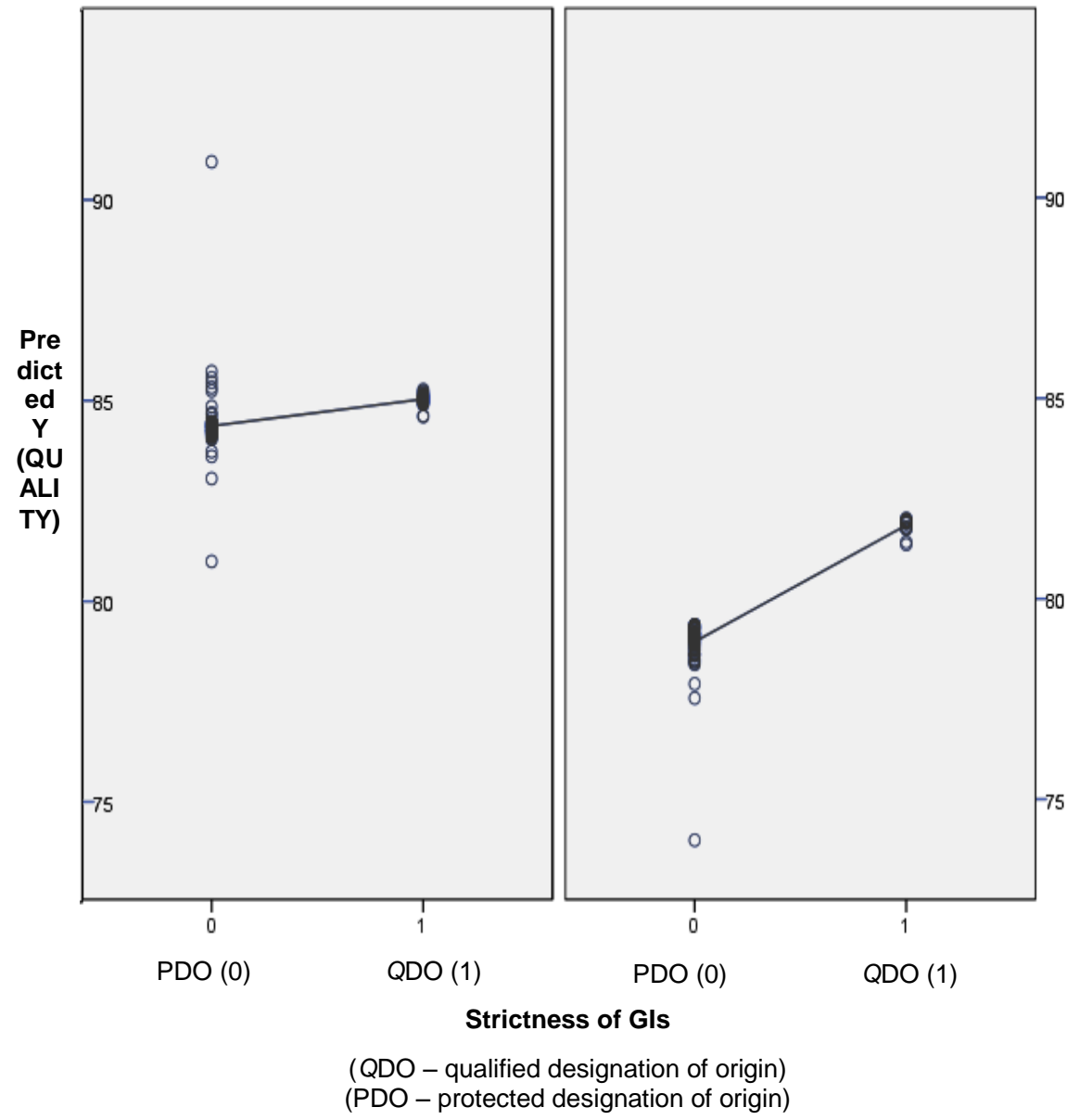

As shown in Figure 1, co-ops always perform worse than IOFs in terms of quality $(\mathrm{H} 2)$, i.e., the co-ops' predicted quality scores in axis (b) are clearly below the IOFs' predicted quality scores in axis (a). Figure 1 also shows how the most stringent GIs (QDO) 
help lower quality dispersion; the standard deviation of quality scores is lower for $Q D O$ (Std. Dev.: 3.265) than for PDO producers (Std. Dev.: 4.353) regardless of the ownership structure (Levene statistic=F: 6.549; Sig. 0.011). However, the figure shows that the $Q D O$ 's positive impact on quality (H1) is more intense in co-ops (shown as a higher slope in the co-op curve) (H3). Moreover, the average quality of IOFs (approximately 84.5) does not appear to be significantly affected by the type of GI in which the wineries are registered, thus reinforcing that whereas co-op organizations benefit from producing under a $Q \mathrm{DO}, \mathrm{IOF}$ do $\operatorname{not}^{6}$.

\section{Discussion and conclusions}

This study contributes to the SCM literature by investigating how SC governance decisions (e.g., either to adopt a more stringent GI or to create a co-op) affect quality performance not only by improving vertical coordination and leveraging resources (e.g., knowledge) of all SC members but also by affecting their incentives toward quality performance. Thus, the stated hypotheses in this paper sustain that (1) adopting more stringent GIs will enhance wine producers' quality in comparison with less stringent GIs (H1); (2) the co-op ownership structure negatively influences the quality performance of wine producers compared to IOFs (H2); and (3) GIs' efficacy in promoting wine quality will be stronger in co-op organizations than in IOFs (H3).

The paper first clarifies the dubious effectiveness of GIs in promoting and enhancing agri-food quality performance (Josling, 2006). Overall, our results complement previous empirical findings regarding the GI's impact on price premiums (see, for example, Boatto et al., 2011; Defrancesco et al., 2012; Galati et al., 2017), by showing that the differentiation ability of GIs may rest on their ability to improve the final quality of a product (i.e., wine).

\footnotetext{
${ }^{6}$ Mann-Whitney $\mathrm{U}$ tests reinforce this idea. The distribution of quality is not the same across $Q D O$ and PDO wines within the group of co-ops (Z: -3.553; Sig.: 0.000). However, the quality distribution does not vary significantly across $Q D O$ and PDO within the group of IOFs (Z: -0.914; Sig.: 0.361).
} 
Furthermore, according to the recent literature that highlights that the level of effectiveness may differ significantly among GIs (Grunert \& Aachmann, 2016), the finer grained question of how different GIs may influence the final quality, depending on their strictness, has been addressed. This complements previous empirical findings (Cacchiarelli et al., 2016b), which have shown a positive association among the most demanding GIs and the willingness of consumers to pay price-premiums. Specifically, our results show a positive relationship between the most stringent ones (i.e., $Q \mathrm{DO}$ in the wine sector) and the quality performance of processor firms (H1); on average, the quality of $Q \mathrm{DO}$ wineries scores 1.2 points higher than the quality of PDO wineries. This result points to the capacity of the most stringent GIs to ensure chain-wide adaptations to quality demands (Wever et al., 2010; Fernández-Barcala et al., 2017) and to facilitate valuable knowledge transfer among supply chain actors (through the control routines developed by their official certification bodies) (Cañada \& Vázquez, 2005). Although we cannot check it directly, this quality improvement effect goes against the assertion that GIs act as a bureaucratic burden that restrains innovation and product enhancement.

Second, the study extends prior research (Handley \& Gray, 2013; Steven et al., 2014) by incorporating the SC ownership structure (co-op vs. IOF) as a relevant governance variable with both direct and moderating effects on quality performance. In this regard, we contribute to the literature in two ways. On the one hand, we address the direct effects of SC ownership on quality by examining how co-ops are negatively associated with the delivery of high-quality wines (H2). Prior studies have reported a positive relationship between the degree of vertical integration and the higher transaction costs linked to high-quality products in the agri-food industry (e.g., Goodhue et al., 2003; Banterle \& Stranieri, 2008; FernándezOlmos et al., 2009; Traversac et al., 2011). However, empirical studies have rarely examined the relationship between the specific ownership structure of the SC (co-ops vs. IOFs) and 
quality. Even if firms are equally integrated, this paper shows that the internal allocation of property rights among suppliers and processors can alter their investment incentives and damage final quality. Our results are consistent with the property rights approach and the premise that the incentive structure of co-ops both increases their vulnerability to collective action problems (e.g., Rao \& Neilsen, 1992; Cook, 1995; Fulton, 1995; Rey \& Tirole, 2007; Nilsson et al., 2012) and complicates the provision of efficient incentives for quality improvement (e.g., Saitone \& Sexton, 2009; Pennerstorfer \& Weiss, 2013). In contrast, IOFs overcome such problems more easily because they can arrange hierarchical controls over their internal supplies or fall back on the reputation of external (independent) suppliers as an effective market safeguard against quality cheating more effectively (i.e., with lower costs). Indeed, after controlling for selection bias problems and other meaningful factors, such as winery size, experience, and type of GI, our results show that the quality scores of IOFs are on average 4.78 points higher than those of the co-ops.

This outcome is also coherent with the theoretical argument, which cannot be directly checked, that informal controls based on the co-op's social capital are insufficient to restrain free-riding and investment horizon problems among wine co-op members. The incentive and disciplinary roles of social norms, as a relational governance mechanism, are central to many studies (e.g., Granovetter, 1985, 2005; Gulati et al., 2005; Gulati \& Nickerson, 2008) and constitute a particularly important strand of the literature on co-ops (e.g., Valentinov, 2004; Österberg \& Nilsson, 2009; Nilsson et al., 2012). This literature highlights that co-op principles (philosophy) are grounded on mutual aid and cooperation to enhance business success. Furthermore, they assume that co-op members have a vested interest in their organization, creating a specific cooperative social capital with the ability to guarantee the provision of quality (e.g., Cechin et al., 2013). However, our study suggests that when there are significant measurement problems and quality becomes non-contractible, as with the 
production of top-quality wines (Vagnarelli, 2000; Goodhue et al., 2003), the co-op's social norms cannot control for free-riding (quality cheating).

On the other hand, this study also highlights the moderating role that ownership structures (co-op vs. IOF) may play in determining the effectiveness of quality certifications (GIs) (H3). The results indicate that the relative benefits of the most stringent GIs (i.e., $Q \mathrm{DO}$ in the wine sector) for improving final quality are intensified in wine co-ops: within the group of co-ops, $Q D O$ producers obtain on average quality scores that are 2.67 points higher than PDO producers. In contrast, these benefits are insignificant under those governance solutions less exposed to collective action problems, such as IOFs.

Overall, considering the ownership structure of the SC as a moderating variable is coherent with contingency analysis and aimed at identifying key variables that are not highly correlated to contextual factors addressed in previous quality management studies (national and industry context, firm size, age, or strategic orientation) (e.g., Das et al., 2000; Zhao et al., 2004; Sousa \& Voss, 2008; Zhang et al., 2012; Lo et al., 2013). Moreover, it contributes to a greater understanding of the nexus between the organizational economics literature and quality management across the SC. Indeed, the findings indicate that management efforts to design and implement quality certifications should also consider the governance context in which they will be applied because governance context can make certifications more or less valuable. In reality, $Q D O$ certifications are more valuable in some scenarios (e.g., co-ops) than in others.

The results also point to several managerial implications for the wine industry. Although co-op firms account for a large share of the wine market in the leading wineproducing countries, they are confronted by an important challenge as customers' preferences evolve toward high-quality wines. The results first suggest that co-ops suffer from an 
important organizational disadvantage because they must overcome both collective action and horizon investment problems, which undermine quality and are smaller in IOFs. Second, this limitation can be substantially alleviated by adopting the most demanding GIs: QDO. Such GIs are positively associated with quality performance in co-ops but not in IOFs. Coops' quality controls alone cannot guarantee output quality either because co-ops' internal controls are not strict enough or because co-op managers do not have enough authority to enforce them, whereas GI's certification body quality controls do have the ability to provide such a guarantee. This indicates that co-op managers should search for external norms and standards (such as GIs) that allow them to force members to comply with quality demands.

The study does not come without limitations. First, to analyze the performance of coops in comparison with IOFs, future research should take into account additional and complex alignments between external quality certification mechanisms (e.g., those provided by GIs) and the new internal governance mechanisms designed by co-ops (new co-op models). The co-op and the IOF have been analyzed as polar forms of SC governance. However, new co-op models that depart from the traditional co-op structure and principles may relax some of the co-op's disadvantages (Chaddad \& Cook, 2004), and thus, its moderating role on the effectiveness of GI. Second, this study is focused on two types of GIs: $Q D O s$ vs. PDOs. Further research is needed to document the comparative influence of (i) registering under the PGI and (ii) not registering under any GI. Finally, focusing on a single industry may limit generalizability. Future empirical research may explicitly address how the specificities of different SCs belonging to different industries may alter the results.

\section{Acknowledgments}

This paper has benefited from the support of the Spanish Ministry of Economy and Competitiveness (MINECO-13-ECO2013-40407R). 


\section{References}

Ali, H.H., Lecocq, S., Visser, M., 2008. The impact of gurus: Parker grades and en primeur wine prices. Economic Journal, 118(529), F158-FF173.

Allen, D.W., Lueck, D., 1998. The nature of the farm. The Journal of Law and Economics, 41(2), 343-386.

Anderson, E., Schmittlein, D.C., 1984. Integration of the sales force: an empirical examination. Rand Journal of Economics, 15(3), 385-395.

Argote, L. 1999. Organizational learning: creating, retaining and transferring knowledge. Boston: Kluwer Academic Publishers.

Ataseven, C., Nair, A., 2017. Assessment of supply chain integration and performance relationships: a meta-analytic investigation of the literature. International Journal of Production Economics, 185, 252-265.

Banterle, A., Stranieri, S., 2008. The consequences of voluntary traceability system for supply chain relationships. An application of transaction cost Economics. Food Policy, 33(6), 560-569.

Barthélemy, J., 2017. The impact of technical consultants on the quality of their clients' products: evidence from the Bordeaux wine industry. Strategic Management Journal, 38(5), 1174-1190.

Belletti, G., Burgassi, T., Marescotti, A., Scaramuzzi, S. 2007. The effects of certification costs on the success of a PDO/PG. In: Theusen, L., Spiller, A., Peupert, M., Jahn, G. (Eds.). Quality management food chain. Wageningen, The Netherlands: Academic Press Publishers, 107-121.

Benjamin, B.A., Podolny, J.M., 1999. Status, quality, and social order in the California wine industry. Administrative Science Quarterly, 44(3), 563-589. 
Bijman, J., Muradian, R., Cechin, A. 2011. Agricultural cooperatives and value chain coordination. In: Helmsing, A.H.J., Vellema, S. (Eds.). Value chains, social inclusion and economic development: contrasting theories and realities. London: Routledge, 82101.

Bijman, W.J.J., Iliopoulos, C., Poppe, K.J., Gijselinckx, C., Hagendorn, K., Hanisch, M., Hendrikse, G.W.J., Kühl, R., Ollila, P., Pyykkonen, P., van der Sangen, G. 2012. Support for farmers' cooperatives, final report. Wageningen: Wageningen University and Research Centre.

Boatto, V., Defrancesco, E., Trestini, S., 2011. The price premium for wine quality signals: does retailers' information provision matter? British Food Journal, 113(5), 669-679.

Boone, C., Özcan, S., 2014. Why do cooperatives emerge in a world dominated by corporations? The diffusion of cooperatives in the U.S. bio-ethanol industry, 19782013. Academy of Management Journal, 57(4), 990-1012.

Bramley, C., Biénabe, E., Kirsten, J., 2009. The economics of geographical indications: towards a conceptual framework for geographical indication research in developing countries. In: Economics of intellectual property. Geneva, Switzerland: World Intellectual Property Organization (WIPO), 109-141.

Broude, T., 2005. Culture, trade and additional protection for geographical indications. Bridges, 9(9), 20-22.

Cacchiarelli, L., Carbone, A., Esti, M., Laureti, T., Sorrentino, A., 2016b. Assessing Italian wine quality and prices: de gustibus non disputandum est. British Food Journal, 118(5), 1006-1024.

Cacchiarelli, L., Carbone, A., Laureti, T., Sorrentino, A., 2016a. The value of the certifications of origin: a comparison between the Italian olive oil and wine markets. British Food Journal, 118(4), 824-839. 
Cechin, A., Bijman, J., Pascucci, S., Zylbersztajn, D., Omta, O., 2013. Quality in cooperatives versus investor-owned firms: evidence from broiler production in Paraná, Brazil. Managerial and Decision Economics, 34(3-5), 230-243.

Chaddad, F.R., Cook, M.L., 2004. Understanding new cooperative models: an ownershipcontrol rights typology. Review of Agricultural Economics, 26(3), 348-360.

Cook, M.L., 1995. The future of U.S. agricultural cooperatives: a neo-institutional approach. American Journal of Agricultural Economics, 77(5), 1153-1159.

Cooperativas Agro-alimentarias de España, 2016. Memoria de Actividades 2015. Available at http://www.agro-alimentarias.coop/ficheros/doc/04983.pdf

Cooperativas Agro-alimentarias de España, 2017. Memoria de Actividades 2016. Available at http://www.agro-alimentarias.coop/ficheros/doc/05372.pdf

Crozet, M., Head, K., Mayer, T., 2012. Quality sorting and trade: firm-level evidence for French wine. The Review of Economic Studies, 79(2), 609-644.

Das, A., Handfield, R.B., Calantone, R.J., Ghosh, S., 2000. A contingent view of quality management-the impact of international competition on quality. Decision Sciences, 31(3), 649-690.

Defrancesco, E., Estrella Orrego, J.E., Gennari, A., 2012. Would 'New World' wines benefit from protected geographical indications in international markets? The case of Argentinean Malbec. Wine Economics and Policy, 1(1), 63-72.

Deselnicu, O.C., Costanigro, M., Souza-Monteiro, D.M., McFadden, D.T., 2013. A metaanalysis of geographical indication food valuation studies: what drives the premium for origin-based labels? Journal of Agricultural and Resource Economics, 38(2), 204219. 
Dimara, E., Petrou, A., Skuras, D., 2004. Agricultural policy for quality and producers' evaluations of quality marketing indicators: a Greek case study. Food Policy, 29(5), 485-506.

Dorobantu, S., Kaul, A., Zelner, B., 2017. Nonmarket strategy research through the lens of new institutional economics: an integrative review and future directions. Strategic Management Journal, 38(1), 114-140.

Dyer, J.H., Nobeoka, K., 2000. Creating and managing a high-performance knowledgesharing network: the Toyota case. Strategic Management Journal, 21(3), 345-367.

Fernández-Barcala, M., González-Díaz, M., Raynaud, E., 2017. Contrasting the governance of supply chains with and without geographical indications: complementarity between levels. Supply Chain Management: an International Journal, 22(4), 305-320.

Fernández-Olmos, M., Rosell-Martínez, J., Espitia-Escuer, M.A., 2009. Vertical integration in the wine industry: a transaction costs analysis on the Rioja DOCa. Agribusiness, 25(2), 231-250.

Flynn, B.B., Huo, B., Zhao, X., 2010. The impact of supply chain integration on performance: a contingency and configuration approach. Journal of Operations Management, 28(1), 58-71.

Fraser, I., 2005. Microeconometric analysis of wine grape supply contracts in Australia. Australian Journal of Agricultural and Resource Economics, 49(1), 23-46.

Frick, B., 2004. Does ownership matter? Empirical evidence from the German wine industry. Kyklos, 57(3), 357-386.

Frohlich, M.T., Westbrook, R., 2001. Arcs of integration: an international study of supply chain strategies. Journal of Operations Management, 19(2), 185-200.

Fulton, M., 1995. The future of Canadian agricultural cooperatives: a property rights approach. American Journal of Agricultural Economics, 77(5), 1144-1152. 
Galati, A., Crescimanno, M., Abbruzzo, A., Chironi, S., Tinervia, S., 2017. The premium price for Italian red wines in new world wine consuming countries: the case of the Russian market. Journal of Wine Research, 28(3), 181-193.

Giagnocavo, C., Vargas-Vasserot, C. 2012. Support for farmers' cooperatives; country report Spain. Wageningen: Wageningen University and Research Centre.

Giunipero, L.C., Hooker, R.E., Joseph-Matthews, S., Yoon, T.E., Brudvig, S., 2008. A decade of SCM literature: past, present and future implications. Journal of Supply Chain Management, 44(4), 66-86.

Goodhue, R.E., Heien, D.M., Lee, H., Sumner, D.A., 2003. Contracts and quality in the California winegrape industry. Review of Industrial Organization, 23(3), 267-282.

Granovetter, M., 1985. Economic action and social structure: the problem of embeddedness. American Journal of Sociology, 91(3), 481-510.

Granovetter, M., 2005. The impact of social structure on economic outcomes. Journal of Economic Perspectives, 19(1), 33-50.

Gray, J.V., Roth, A.V., Leiblein, M.J., 2011. Quality risk in offshore manufacturing: evidence from the pharmaceutical industry. Journal of Operations Management, 29(78), 737-752.

Gray, J.V., Tomlin, B., Roth, A.V., 2009. Outsourcing to a powerful contract manufacturer: the effect of learning-by-doing. Production and Operations Management, 18(5), 487505.

Grossman, S.J., Hart, O.D., 1986. The costs and benefits of ownership: a theory of vertical and lateral integration. Journal of Political Economy, 94(4), 691-719.

Grunert, K.G., Aachmann, K., 2016. Consumer reactions to the use of EU quality labels on food products: a review of the literature. Food Control, 59, 178-187. 
Gulati, R., Lawrence, P.R., Puranam, P., 2005. Adaptation in vertical relationships: beyond incentive conflict. Strategic Management Journal, 26(5), 415-440.

Gulati, R., Nickerson, J.A., 2008. Interorganizational trust, governance choice, and exchange performance. Organization Science, 19(5), 688-708.

Guo, S., Fraser, M.W. 2009. Propensity score analysis: statistical methods and applications. Thousand Oaks, CA: SAGE Publications.

Hair, J.F., Tatham, R., Anderson, R., Black, W. 1995. Multivariate data analysis: with readings. 4th ed. Englewood Cliffs, NJ: Prentice Hall.

Hamilton, B.H., Nickerson, J.A., 2003. Correcting for endogeneity in strategic management research. Strategic Organization, 1(1), 51-78.

Handley, S.M., Gray, J.V., 2013. Inter-organizational quality management: the use of contractual incentives and monitoring mechanisms with outsourced manufacturing. Production and Operations Management, 22(6), 1540-1556.

Hansmann, H. 1996. The ownership of enterprise. Cambridge, MA: Harvard University Press.

Hart, O., Moore, J.., 1990. Property rights and the nature of the firm. Journal of Political Economy, 98(6), 1119-1158.

Heckman, J.J., 1979. Sample selection bias as a specification error. Econometrica, 47(1), 153-161.

Heide, J.B., Kumar, A., Wathne, K.H., 2014. Concurrent sourcing, governance mechanisms, and performance outcomes in industrial value chains. Strategic Management Journal, 35(8), 1164-1185.

Hendrikse, G., 2011. Pooling, access, and countervailing power in channel governance. Management Science, 57(9), 1692-1702. 
Hennessy, D.A., 1996. Information asymmetry as a reason for food industry vertical integration. American Journal of Agricultural Economics, 78(4), 1034-1043.

Hobbs, J.E., 1996. A transaction cost approach to supply chain management. Supply Chain Management, 1(2), 15-27.

Holmstrom, B., Milgrom, P., 1991. Multitask principal-agent analyses: incentive contracts, asset ownership, and job design. Journal of Law, Economics, and Organization, 7, 2452.

Huo, B., Ye, Y., Zhao, X., Zhu, K., 2016. Supply chain quality integration: a taxonomy perspective. International Journal of Production Economics. doi:10.1016/j.ijpe.2016.05.004.

International Organisation of Vine and Wine (IOV), 2017. World Vitiviniculture Situation. Available at http://www.oiv.int/public/medias/5479/oiv-en-bilan-2017.pdf

Josling, T., 2006. The war on terroir: geographical indications as a transatlantic trade conflict. Journal of Agricultural Economics, 57(3), 337-363.

Kaynak, H., Hartley, J.L., 2008. A replication and extension of quality management into the supply chain. Journal of Operations Management, 26(4), 468-489.

Kim, J., Mahoney, J.T., 2005. Property rights theory, transaction costs theory, and agency theory: an organizational economics approach to strategic management. Managerial and Decision Economics, 26(4), 223-242.

Kim, S.W., 2009. An investigation on the direct and indirect effect of supply chain integration on firm performance. International Journal of Production Economics, 119(2), 328-346.

Koufteros, X., Vonderembse, M., Jayaram, J., 2005. Internal and external integration for product development: the contingency effects of uncertainty, equivocality, and platform strategy. Decision Sciences, 36(1), 97-133. 
Koufteros, X.A., Edwin Cheng, T.C.E., Lai, K.-H., 2007. "Black-box" and "gray-box" supplier integration in product development: antecedents, consequences and the moderating role of firm size. Journal of Operations Management, 25(4), 847-870.

Lafontaine, F., Slade, M., 2007. Vertical integration and firm boundaries: the evidence. Journal of Economic Literature, 45(3), 629-685.

Lence, S.H., Marette, S., Hayes, D.J., Foster, W., 2007. Collective marketing arrangements for geographically differentiated agricultural products: welfare impacts and policy implications. American Journal of Agricultural Economics, 89(4), 947-963.

Leuschner, R., Rogers, D.S., Charvet, F.F., 2013. A meta-analysis of supply chain integration and firm performance. Journal of Supply Chain Management, 49(2), 34-57.

Lewis, G.K., Byrom, J., Grimmer, M., 2015. Collaborative marketing in a premium wine region: the role of horizontal networks. International Journal of Wine Business Research, 27(3), 203-219.

Liang, Q., Hendrikse, G.W.J., 2013. Pooling and the yardstick effect of cooperatives. In: Proceedings of the 17th Annual Conference of the International Society for New Institutional Economics (ISNIE), Florence, June 20-22, 2013.

Lo, C.K.Y., Wiengarten, F., Humphreys, P., Yeung, A.C.L., Cheng, T.C.E., 2013. The impact of contextual factors on the efficacy of ISO 9000 adoption. Journal of Operations Management, 31(5), 229-235.

London Economics, 2008. Evaluation of the CAP policy on protected designations of origin (PDO) and protected geographical indications (PGI), final report. London: London Economics.

Loureiro, M.L., Umberger, W.J., 2007. A choice experiment model for beef: what US consumer responses tell us about relative preferences for food safety, country-oforigin labeling and traceability. Food Policy, 32(4), 496-514. 
Maddala, G.S. 1983. Limited-dependent and qualitative variables in econometrics. Cambridge: Cambridge University Press.

Maher, M., 2001. On vino veritas? Clarifying the use of geographic references on American wine labels. California Law Review, 89(6), 1881-1925.

MAPAMA, 2004. Estudio sobre la comercialización agroalimentaria en el sector cooperativo español. Madrid: Ministry of Agriculture and Fisheries, Food, and Environment.

MAPAMA, 2006. Datos de los vinos de calidad producidos en regiones determinadas (vcprd), CAMPAÑA 2005/2006, subdirección general de calidad agroalimentaria y agricultura ecológica. Madrid: Ministry of Agriculture and Fisheries, Food, and Environment.

MAPAMA, 2017a. Fichas sectoriales de la industria alimentaria. Informe Sector Vinos. Available at http://www.mapama.gob.es/es/alimentacion/temas/industriaagroalimentaria/11f_vinosabril-17_tcm7-270414.pdf

MAPAMA, 2017b. Encuesta de viñedo 2015. Available at http://www.mapama.gob.es/es/estadistica/temas/estadisticasagrarias/memofinalvinedo_tcm7-443391.pdf

Masten, K.A., Kim, S.-L., 2015. So many mechanisms, so little action: the case for 3rd party supply chain coordination. International Journal of Production Economics, 168, 1320.

Masten, S.E. 1996. Empirical research in transaction cost economics: challenges, progress, directions. In: Groenewegen, J. (Ed.). Transaction cost economics and beyond. Boston: Kluwer Academic Publishers, 43-64.

Mellat-Parast, M., Digman, L.A., 2008. Learning: the interface of quality management and strategic alliances. International Journal of Production Economics, 114(2), 820-829. 
Ménard, C., Valceschini, E., 2005. New institutions for governing the agri-food industry. European Review of Agricultural Economics, 32(3), 421-440.

Mérel, P., Sexton, R.J., 2012. Will geographical indications supply excessive quality? European Review of Agricultural Economics, 39(4), 567-587.

Mérel, P.R., Saitone, T.L., Sexton, R.J., 2009. Cooperatives and quality-differentiated markets: strengths, weaknesses, and modeling approaches. Journal of Rural Cooperation, 37(2), 201-224.

Narasimhan, R., Nair, A., 2005. The antecedent role of quality, information sharing and supply chain proximity on strategic alliance formation and performance. International Journal of Production Economics, 96(3), 301-313.

Nilsson, J., 2001. Organisational principles for co-operative firms. Scandinavian Journal of Management, 17(3), 329-356.

Nilsson, J., Svendsen, G.L.H., Svendsen, G.T., 2012. Are large and complex agricultural cooperatives losing their social capital? Agribusiness, 28(2), 187-204.

Oczkowski, E., 1994. A hedonic price function for Australian premium table wine. Australian Journal of Agricultural Economics, 38(1), 93-110.

Österberg, P., Nilsson, J., 2009. Members' perception of their participation in the governance of cooperatives: the key to trust and commitment in agricultural cooperatives. Agribusiness, 25(2), 181-197.

Ostrom, E., 2010. Beyond markets and states: polycentric governance of complex economic systems. American Economic Review, 100(3), 641-672.

Peñín, J. 2006. Guia Peñin de los Vinos de España 2006. Madrid: Peñín Ediciones.

Pennerstorfer, D., Weiss, C.R., 2013. Product quality in the agri-food chain: do cooperatives offer high-quality wine? European Review of Agricultural Economics, 40(1), 143162. 
Ponte, S., 2009. Governing through quality: conventions and supply relations in the value chain for South African wine. Sociologia Ruralis, 49(3), 236-257.

Powell, W.W., Koput, K.W., Smith-Doerr, L., 1996. Interorganizational collaboration and the locus of innovation: networks of learning in biotechnology. Administrative Science Quarterly, 41(1), 116-145.

Rao, H., Neilsen, E.H., 1992. An ecology of agency arrangements: mortality of savings and loan associations, 1960-1987. Administrative Science Quarterly, 37(3), 448-470.

Rey, P., Tirole, J., 2007. Financing and access in cooperatives. International Journal of Industrial Organization, 25(5), 1061-1088.

Rippon, M.J., 2014. What is the geography of geographical indications? Place, production methods and protected food names. Area, 46(2), 154-162.

Robinson, C.J., Malhotra, M.K., 2005. Defining the concept of supply chain quality management and its relevance to academic and industrial practice. International Journal of Production Economics, 96(3), 315-337.

Rosenzweig, E.D., Roth, A.V., Dean Jr, J.W., 2003. The influence of an integration strategy on competitive capabilities and business performance: an exploratory study of consumer products manufacturers. Journal of Operations Management, 21(4), 437456.

Ross, D.F. 1998. Competing through supply chain management. New York: Springer Verlag Science \& Business Media.

Saitone, T.L., Sexton, R.J., 2009. Optimal cooperative pooling in a quality-differentiated market. American Journal of Agricultural Economics, 91(5), 1224-1232.

Sanz Cañada, J., Macías Vázquez, A., 2005. Quality certification, institutions and innovation in local agro-food systems: protected designations of origin of olive oil in Spain. Journal of Rural Studies, 21(4), 475-486. 
Schoenherr, T., Swink, M., 2012. Revisiting the arcs of integration: cross-validations and extensions. Journal of Operations Management, 30(1-2), 99-115.

Scott-Morton, F.M., Podolny, J.M., 2002. Love or money? The effects of owner motivation in the California wine industry. Journal of Industrial Economics, 50(4), 431-456.

Shaver, J.M., 1998. Accounting for endogeneity when assessing strategy performance: does entry mode choice affect FDI survival? Management Science, 44(4), 571-585.

Sila, I., Ebrahimpour, M., Birkholz, C., 2006. Quality in supply chains: an empirical analysis. Supply Chain Management, 11(6), 491-502.

Soboh, R., Oude Lansink, A.O., Van Dijk, G., 2012. Efficiency of cooperatives and investor owned firms revisited. Journal of Agricultural Economics, 63(1), 142-157.

Sousa, R., Voss, C.A., 2008. Contingency research in operations management practices. Journal of Operations Management, 26(6), 697-713.

Staatz, J.M. 1987. Farmers' incentives to take collective action via cooperatives: a transaction-cost approach. In: Royer, J.S., Mengel, J.R. (Eds.). Cooperative theory: new approaches, Agricultural cooperative service. Washington, DC: United States Department of Agriculture, 87-107.

Steven, A.B., Dong, Y., Corsi, T., 2014. Global sourcing and quality recalls: an empirical study of outsourcing-supplier concentration-product recalls linkages. Journal of Operations Management, 32(5), 241-253.

Swink, M., Narasimhan, R., Wang, C., 2007. Managing beyond the factory walls: effects of four types of strategic integration on manufacturing plant performance. Journal of Operations Management, 25(1), 148-164.

Tennbakk, B., 2004. Cooperatives, regulation and competition in Norwegian agriculture. Food Economics - Acta Agriculturae Scandinavica, Section C, 1(4), 232-240. 
Traversac, J.B., Rousset, S., Perrier-Cornet, P., 2011. Farm resources, transaction costs and forward integration in agriculture: evidence from French wine producers. Food Policy, 36(6), 839-847.

Vagnarelli, B. 2000. Targeting and achieving quality improvements. In: Davies, C., Dundon, C., Hamilton, R. (Eds.). Modern viticulture-meeting market specifications. Adelaide: Australian Society of Viticulture and Oenology, 30-32.

Valentinov, V.L., 2004. Toward a social capital theory of cooperative organisation. Journal of Cooperative Studies, 37(3), 5-20.

Vanichchinchai, A., Igel, B., 2011. The impact of total quality management on supply chain management and firm's supply performance. International Journal of Production Research, 49(11), 3405-3424.

Vitaliano, P., 1983. Cooperative enterprise: an alternative conceptual basis for analyzing a complex institution. American Journal of Agricultural Economics, 65(5), 1078-1083.

Wever, M., Wognum, N., Trienekens, J., Omta, O., 2010. Alignment between chain quality management and chain governance in EU pork supply chains: a transaction-costeconomics perspective. Meat Science, 84(2), 228-237.

Wever, M., Wognum, P.M., Trienekens, J.H., Omta, S.W.F., 2012. Supply chain-wide consequences of transaction risks and their contractual solutions: towards an extended transaction cost economics framework. Journal of Supply Chain Management, 48(1), 73-91.

Wiggins, S.N., Libecap, G.D., 1985. Oil field unitization: contractual failure in the presence of imperfect information. American Economic Review, 75(3), 368-385.

Williamson, O.E., 2008. Outsourcing: transaction cost economics and supply chain management. Journal of Supply Chain Management, 44(2), 5-16. 
Winfree, J.A., McCluskey, J.J., 2005. Collective reputation and quality. American Journal of Agricultural Economics, 87(1), 206-213.

Wong, C.Y., Boon-Itt, S., Wong, C.W.Y., 2011. The contingency effects of environmental uncertainty on the relationship between supply chain integration and operational performance. Journal of Operations Management, 29(6), 604-615.

Zhang, D., Linderman, K., Schroeder, R.G., 2012. The moderating role of contextual factors on quality management practices. Journal of Operations Management, 30(1-2), 12-23.

Zhao, X., Yeung, A.C.L., Lee, T.S., 2004. Quality management and organizational context in selected service industries of China. Journal of Operations Management, 22(6), 575587.

Ziggers, G.W., Trienekens, J., 1999. Quality assurance in food and agribusiness supply chains: developing successful partnerships. International Journal of Production Economics, 60-61, 271-279. 